Volume 11 Nomor 1, November 2019, p. 062 - 076

Faculty of Law, Universitas Kristen Maranatha

ISSN: 2085-9945 I e-ISSN: 2579-3520

Nationally Accredited Journal by SINTA

\title{
PERLINDUNGAN HUKUM BAGI KONSUMEN TERHADAP IKLAN \\ TELEVISI YANG BERMUATAN MATERI PORNOGRAFI MELALUI CLASS
}

\section{ACTION}

\author{
Radhyca Nanda Pratama dan Akbar Fitri Yanto Sholehudin
}

Bagian Hukum, Universitas Negeri Surabaya - Surabaya

radhycanp@gmail.com

Submitted: 2019-05-07| Reviewed: 2019-11-04 | Accepted: 2019-11-19

\begin{abstract}
Advertising is direct communication media from producer (businessman) to audience / potential consumers and consumers, of course it is expected by producers, one of them is introduce the product (both goods and services) to consumers and hopes consumers, through persuasion, are willing to consume them. However, there are some advertisement that are aired on television that contain pornography that does not meet criteria that determined by KPI, one of them is SidoSusu advertisement. Based on these considerations, the authors are interested in conducting research related to Legal Protection for Consumers toward Television Advertisements with Pornographic Material through Class Action. This research aims to provide legal protection for costumers that caused by advertisement that containing pornographic material and legal effort to claim compensation for inconvenience of ad impressions due to pornography through Class Action lawsuits. This research uses normative juridical research type with research, statue approach and conceptual approach. The results showed the existence of consumer rights that is the right to obtain comfort, security and safety in buying goods and / or services, the validity of these rights involved the same compilation of consumers who bought ads purchased by advertising companies. It uses legal construction method, argumentum per analogiam. So that consumer who are disadvantaged. Because of advertaisement that containing pornography can request class action compensation claims.
\end{abstract}

Keywords: Advertisement; class action; legal protection.

\section{PENDAHULUAN}

Dalam lalu lintas kegiatan ekonomi, kegiatannya pun tidak hanya berkaitan dengan produksi, distribusi, dan konsumsi. Tidak berhenti pada kegiatan tersebut saja namun juga untuk memperkenalkan produknya dan menarik minat para konsumennya dengan 
Dialogia luridica: Jurnal Hukum Bisnis dan Investasi

Vol. 11 (1): 062- 076

harapan untuk membeli dan mengkonsumsi produknya, pelaku usaha melakukan promosi terhadap produk yang di menjualnya. Promosi ini pun bermacam-macam caranya, salah satunya melalui iklan.

Iklan adalah salah satu sarana yang digunakan oleh pelaku usaha untuk mempromosikan produknya baik berupa barang/jasa. Setiap hari iklan yang baik ditayangkan melalui televisi, radio, maupun media cetak, digunakan oleh hampir pelaku usaha untuk mendukung kegiatan promosi mereka. Tidak ada satupun pelaku usaha dalam melakukan pemasaran berani menafikan keberadaan iklan

Iklan merupakan media komunikasi langsung dengan produsen (Pelaku usaha) kepada audiens/calon konsumen maupun konsumen, tentu saja di sini yang diharapkan oleh produsen salah satunya mengenalkan produk (baik barang maupun jasa) kepada konsumen dan berharap konsumen, melalui persuasi, bersedia mengkonsumsinya. ${ }^{1}$

Di zaman modern seperti sekarang ini dengan kemajuan teknologi yang semakin pesat, pelaku usaha menggunakan siaran melalui televisi untuk menayangkan iklan produknya. Siaran melalui televisi dinilai mampu menarik minat konsumsi tinggi karena siaran iklan akan lebih menarik dan tampilan audio visual dengan kreatifitas di dalamnya yang unik.

Namun perlu diketahui dalam penayangan sebuah iklan juga perlu dan wajib mematuhi etika penyiarannya sesuai dengan ketentuan peraturan perundang-undangan. Mau tidak mau suka tidak suka pelaku usaha harus memperhatikan rambu-rambu peratura tersebut akan dikemudian hari tidak menimbulkan permasalahan yang merugikan konsumen di suatu hari kemudian akibat siaran iklan tersebut.

Pada awal tahun 2019 adapun permasalahan terkait pelanggaran etika periklanan oleh pelaku usaha periklanan, media penyiaran iklan (stasiun televisi), dan pelaku usaha pemesan iklan selaku pemilik produk yang bersangkutan yang bersangkutan. Pelanggaran tersebut dilakukan melibatkan pelaku usaha ternama yang mana memiliki peran andil besar dalam dunia pertelevisian di Indonesia dan pelaku usaha dengan produk andalan jamu yang terkenal. Secara umum, jenis iklan terdapat dalam Etika Pariwara Indonesia antara lain : Iklan Korporat, Iklan Layanan Masyarakat, Iklan Produk Pangan, Iklan Televisi Imbo, Iklan Televisi Nirkomersial, Iklan Televisi

\footnotetext{
${ }^{1}$ Mardian Wibowo, Iklan Televisi dan Perlindungan Hukum Bagi Konsumen, Bandung: Mandar Maju,
} 2018, hlm. 3. 
Dialogia luridica: Jurnal Hukum Bisnis dan Investasi

Vol. 11 (1): 062- 076

Komersial. ${ }^{2}$ Apabila diamati dalam siaran iklan pada stasiun televisi terdapat beberapa iklan yang menunjukan adegan tidak pantas ditampilkan pada suatu iklan, artinya iklan tersebut mengandung unsur pornografi, sebagai berikut data iklan yang disiarkan di stasiun televisi ditegur oleh KPI:

\section{Tabel 1.1}

Iklan Yang ditegur oleh KPI

\begin{tabular}{|c|c|c|c|}
\hline No & Siaran Iklan & $\begin{array}{c}\text { Stasiun Televisi } \\
\text { Yang Ditegur }\end{array}$ & Surat Edaran Teguran \\
\hline 1. & Iklan Sido Susu & $\begin{array}{l}\text { TV One, SCTV, } \\
\text { ANTV, Indosiar }\end{array}$ & $\begin{array}{ll}1 . & / \mathrm{K} / \mathrm{KPI} / 31.2 / 12 / 01 / 2019 \\
\text { 2. } & 26 / \mathrm{K} / \mathrm{KPI} / 31.2 / 12 / 01 / 2019 \\
\text { 3. } & 28 / \mathrm{K} / \mathrm{KPI} / 31.2 / 12 / 01 / 2019 \\
\text { 4. } & 27 / / \mathrm{K} / \mathrm{KPI} / 31.2 / 12 / 01 / 2019\end{array}$ \\
\hline 2. & $\begin{array}{l}\text { Iklan Pompa Air } \\
\text { Shimizu. }\end{array}$ & RCTI & 1. $514 / \mathrm{K} / \mathrm{KPI} / 08 / 12$ \\
\hline 3. & Iklan Cat Avian & TRANS 7 & 1. $378 / \mathrm{K} / \mathrm{KPI} / 07 / 13$ \\
\hline
\end{tabular}

Sumber: Komisi Penyiaran Indonesia

Berdasarkan surat teguran diatas, jenis iklan yang mendapat surat teguran oleh KPI merupakan iklan niaga. Dikategorikan sebagai suatu iklan niaga, apabila iklan tersebut dalam materi yang termuat dalam iklan tersebut bersifat komersial, artinya tujuan diadakan iklan tersebut adalah untuk melakukan promosi terhadap barang atau jasa yang ditawarkan oleh pelaku usaha selaku pemesan iklan yang kemudian iklan tersebut diproduksi oleh perusahaan periklanan.

Komisi Penyiaran Indonesia yang selanjutnya disebut KPI telah memberikan peringatan dan teguran terhadap beberapa stasiun televisi dikarenakan diduga berpotensi melanggar etika periklanan sebagaimana telah diatur dalam peraturan perundangundangan terkait. Pemberian peringatan tersebut ditujukan kepada empat stasiun televisi yang telah menayangkan "Iklan SidoSusu". Iklan tersebut dinilai berpotensi melanggar dan tidak pantas tayang karena bertentangan dengan norma kesopanan serta perlindungan terhadap anak dalam P3SPS.

\footnotetext{
${ }^{2}$ Dewan Periklanan Indonesia, Etika Pariwara Indonesia Amandemen 2014, Jakarta: Dewan Periklanan Indonesia, 2014, hlm. 16-17.
} 
Dialogia luridica: Jurnal Hukum Bisnis dan Investasi

Vol. 11 (1): 062- 076

Program iklan tersebut menampilkan adegan seorang perempuan (Cupi Cupita) menyampaikan informasi komersial dengan menggerak-gerakkan bagian dadanya. Hal itu berpotensi melanggar Pasal 9 dan Pasal 15 Ayat (1) SPS KPI Tahun 2012 tentang kewajiban program siaran memperhatikan norma kesopanan dan kesusilaan yang dijunjung oleh keberagaman khalayak terkait budaya serta kewajiban program siaran melindungi kepentingan anak. Maka dengan keberadaan iklan tersebut yang ditayangkan pada televisi.

Dalam posisi seperti ini pula konsumen juga dirugikan akibat tayangan iklan tersebut. Adapun kerugian yang dirasakan oleh konsumen merupakan kerugian immateril, yang mana dengan adanya kerugian immaterial hal ini identika dengan perbuatan melanggar hukum (vide Pasal 1365 KUH Perdata). Serta tayangan iklan tersebut telah di lihat oleh khalayak umum, maka hal ini juga kerugian yang diderita oleh konsumen berdampak masif dan meluas karena melibatkan banyaknya kepentingan konsumen yang sama-sama karena dirugikan akibat iklan tersebut maka hal ini berlaku pula Gugatan Perwakilan Kelompok atau biasa dikenal dengan istilah Class Action.

\section{PEMBAHASAN}

\section{Pengaturan Iklan dan Larangan Iklan Yang Tidak Boleh Disiarkan}

Istilah iklan dalam Bahasa asing, misalnya, dalam bahasa Inggris: adverstisement, adverstising; bahasa Belanda: advertentil; dan bahasa Indonesia: pariwara, iklan, artinya setiap bentuk penyajian apapun penyajian apa pun untuk sebuah produk, ide atau gagasan-gagasan oleh sponsor dan menggunakan media, seperti majalah, radio, televisi, ataupun surat kabar. ${ }^{3}$

PengertianSecara yuridis iklan dapat merujuk pada ketentuan Pasal 1 angka 13 Peraturan Menteri Kesehatan Republik Indonesia Nomor 329/Menkes/PER/XII/76 tentang Produksi dan Peradaran Makanan menyebutkan "Iklan adalah usaha dengan cara apa pun untuk meningkatkan penjualan, baik secara langsung maupun tidak langsung”.

\footnotetext{
${ }^{3}$ Janus Sidabalok, Hukum Perlindungan Konsumen di Indonesia, Cetakan ke III, Bandung: Citra Aditya Bakti, 2014, hlm. 226
} 
Dialogia luridica: Jurnal Hukum Bisnis dan Investasi

Vol. 11 (1): 062- 076

Ada beberapa pengertian iklan yang dikemukakan oleh para sarjana atau mengenai Iklan sebagimana berikut:

\section{Menurut paparan Philip Kotler:}

"Iklan adalah komunikasi bukan pribadi, yang dilakukan melalui media yang dibayar atas usaha yang jelas"4

\section{Menurut Janus Sidabalok:}

"Iklan adalah suatu bentuk komunikasi, untuk promosi, memakai jasa media, dan ada sposonsornya. Tampak bahwa ada sekurang-kurangnya tiga pihak yang terlibat di dalamnya, yaitu, pemesan iklan (pemilik produk yang diiklankan), perusahaan media yang mengiklankan (agen periklanan), dan masyarakat pemirsa/pembaca sebagai konsumen"

Terkait pengaturan iklan sendiri secara umbrella act diatur dalam Undang-Undang Nomor 32 Tahun 2002 tentang penyiaran yang secara spesifik dalam Undang-Undang tersebut hanya mengatur terkait secara umum yang berkaitan dengan penyiaran suatu iklan. Tujuan iklan bergantung pada keputusan yang diambil oleh management berkaitan dengan pasar target, posisi di pasar dan bawaan pemasaran. Kotler mengklasifikasikan kedalam tiga macam tujuan iklan, yaitu menyampaikan informasi, membujuk, dan mengingatkan. ${ }^{6}$

Melalui iklan, pelaku usaha bermaksut mengkomunikasikan sesuatu yang berkaitan dengan produknya kepada konsumen. Karena pelaku usaha menempuh berbagai macam cara yang dianggap dapat menyampaikan pesannya secara efektif dan efisien. Pelaku usaha juga memilih media yang dianggap lebih tepat untuk itu. Berkaca dari latar belakang pendidikan, status social, budaya, suku bangsa, agama, dan lain-lain dari konsumen sasaran ikut pula mempengaruhi strategi pelaku usaha untuk mengiklankan produknya. $^{7}$

Berkaitan dengan penayangan iklan hendaknya pelaku usaha harus berhati-hati dalam memberi janji atau jaminan dan materi muatan dalam iklan yang akan ditayangkan. Manakala pelaku usaha menayangkan materi muatan iklan yang tidak

\footnotetext{
${ }^{4}$ Philip Kotler, Manajemen Pemasaran; Analisis, Perencanaan, dan Pengendalian, Jilid II, Edisi Kelima, Jakarta: Erlangga, 1994, hlm. 237 dalam Janus Sidabalok, ibid, hlm. 227.

${ }^{5}$ Idem.

${ }^{6}$ Kotler, op.cit, hlm. 270.

${ }^{7}$ Janus Sidobalok, op.cit, hlm. 228.
} 
Dialogia luridica: Jurnal Hukum Bisnis dan Investasi

Vol. 11 (1): 062- 076

sesuai dengan peraturan perundang-undangan maka akan menimbulkan akibat hukum berupa sebuah pertanggung jawaban akibat tayangan iklan tersebut,

Larangan suatu iklan yang tidak boleh ditayangkan maupun diproduksi yakni mengacu pada ketentuan merujuk pada ketentuan pasal 17 UU Nomor 8 Tahun 1999 Tentang Perlindungan Konsumen sebagaimana berikut bunyinya:

Pelaku usaha periklanan dilarang memproduksi iklan yang:

a. Mengelabui konsumen mengenai kualitas, kuantitas, bahan kegunaan, dan harga barang dan/atau jasa serta ketepatan waktu penerimaan barang dan/atau jasa.

b. Mengelabui jaminan/garansi terhadap barang dan/atau jasa

c. Memuat informasi yang keliru, salah atau tidak tepat mengenai barang dan atau/jasa:

d. Tidak memuat informasi mengenai resiko pemakaian barang dan/atau jasa;

e. Mengeksploitasi kejadian dan/atau seseorang tanpa seizin yang berwenang atau persetujuan yang bersangkutan.

f. Melanggar etikadan/atau ketentuan peraturan perundang-undangan mengenai periklanan.

Merujuk pada ketentuan pasal 17 ayat (1) hruf f UUPK ketentuan tersebut ada kaitannya dengan ketentuan pasal 46 ayat (3) UU No. 32 Tahun 2002 Tentang Penyiaran, bahwa:

Siaran iklan niaga dilarang melakukan:

a. Promosi yang dihubungkan dengan ajaran suatu agama, ideologi pribadi dan/atau kelompok, yang menyinggung perasaan dan/atau merendahkan martabat agama lain, ideologi lain, pribadi lain, atau kelompok lain;

b. Promosi minuman keras atau sejenisnya dan bahan atau zat adiktif

c. Promosi rokok yang memperagakan wujud rokok;

d. Hal-hal yang bertentangan dengan kesusilaan masyarakat dan nilainilai agama dan/atau

e. Eksploitasi anak dibawah umur 18 (delapan belas) tahun.

Berkaitan dengan ketentuan dua pasal diatas adapun sifat pelanggaran yang ditemukan yakni perbuatan melanggar hukum. Dalam hal ini perbuatan yang dilakukan 
Dialogia luridica: Jurnal Hukum Bisnis dan Investasi

Vol. 11 (1): 062- 076

ketika dalam memproduksi hingga menayangkan iklan tersebut tidak memperhatikan ketentuan peraturan Perundang-undangan terkait periklanan.

\section{Pertanggungjawaban Keperdataan Terhadap Siaran Iklan}

Berkenaan perbuatan melanggar hukum terhadap suatu siaran iklan menimbulkan akibat hukum berupa pertanggungjawaban keperdataan. Secara konsep perbuatan melawan hukum adalah suatu kumpulan dari prinsip-prinsip hukum yang bertujuan mengontrol atau mengatur perilaku berbahaya, untuk memberikan tanggung jawab atas suatu kerugian yang terbit dari interaksi sosial, dan untuk menyediakan ganti rugi terhadap korban dengan suatu gugatan yang tepat. ${ }^{8}$ pengaturan perbuatan melanggar hukum dapat dijumpai dalam pasal 1365 KUHPerdata "Tiap perbuatan melanggar hukum yang membawa kerugian kepada seorang lain, mewajibkan orang yang karena salahnya menerbitkan kerugian itu, mengganti kerugian tersebut."

Adapun unsur-unsur dari perbuatan melawan hukum sesuai dengan ketentuan Pasal 1365 KUHPerdata:

1) Adanya suatu perbuatan

Suatu perbuatan melawan hukum diawali suatu perbuatan dari si pelakunya. Umumnya diterima anggapan bahwa dengan perbuatan disini dimaksudkan baik berbuat sesuatu dalam artian aktif maupun tidak berbuat sesuatu dalam arti pasif. Dalam iklan "SidoSusu" perbuatan pelaku usaha periklanan yang dimaksud adalah pasif karena dalam peraturan perundang-undangan terkait periklanan sudah jelas melarang pelaku usaha untuk tidak menayangkan dan memproduksi sebuah iklan yang melanggar kesusilaan artinya pelaku usaha dikatakan dalam artian aktif karena berbuat sesuatu yang melanggar suatu undang-undang, seharusnya perbuatan yang dilakukan pelaku usaha adalah dalam artian pasif, artinya pelaku usaha periklanan tidak boleh melanggar ketentuan peraturan perundang-undang periklanan.

2) Perbuatan tersebut melawan hukum

Perbuatan yang dilakukan tersebut haruslah melawan hukum. Unsur-unsur melawan hukum ini diartikan yang seluas-luasnya, yakni meliputi hal-hal sebagai berikut:

\footnotetext{
${ }^{8}$ Munir Fuadi, Perbuatan Melawan Hukum, Bandung: Citra Aditya, 2017, hlm 3.
} 
a) perbuatan yang melanggar undang-undang yang berlaku;

b) melanggar hak orang lain yang dijamin oleh hukum;

c) perbuatan yang bertentangan dengan kewajiban hukum si pelaku;

d) perbuatan yang bertentangan dengan kesusilaan;

e) perbuatan yang bertentangan dengan sikap yang baik dalam bermasyarakat untuk memperhatikan kepentingan orang lain.

Dalam kasus iklan "SidoSusu" berdasarkan unsur-unsur perbuatan melawan yang dilakukan perusahaan periklanan/media penyiar iklan dan pelaku usaha pemesan iklan memenuhi unsur huruf a, c, dan d.

3) Adanya kesalahan dari pelaku

Agar dapat dikenakan pasal 1365 BW tentang perbuatan melawan hukum haruslah mengandung unsur kesalahan dalam suatu pebuatan melawan hukum, perlu diketahui bagaimanakah cakupan dari unsur kesalahan tersebut. Unsurunsurnya kesalahan agar dapat dimintakan pertanggungjawaban secara hukum jika memenuhi sebagai berikut:

a) Adanya unsur kesengajaan;

b) Adanya unsur kelalaian;

c) Tidak ada alasan pembenar atau alasan pemaaf.

Dalam penerapannya pada iklan "SidoSusu" terpenuhi unsur kesengajaan memproduksi iklan tersebut secara sengaja menampilkan adegan pada tayangan iklan yang seharusnya tidak boleh ditampilkan.

4) Adanya kerugian bagi korban

Adanya kerugian bagi korban juga merupakan syarat agar gugatan berdasarkan pasal 1365 BW dapat dipergunakan. Dalam kerugian karena perbuatan melawan hukum disamping kerugian materiiel ada juga kerugian immaterial yang juga akan dinilai dengan uang. Masyarakat selaku konsumen lebih condong dirugikan secara immaterial ketika melihat tayang iklan "SidoSusu". Karena muatan tayangan iklan tersebut menurut kami tidak memberikan kesan nyaman karena terdapat adegan yang tidak pantas untuk dipertontonkan.

Parameter untuk menentukan sebuah siaran iklan memenuhi standar kenyamanan adalah tidak melanggar norma kesopanan dan norma kesusilaan. 
Norma kesopanan merukan norma yang diciptakan untuk mewujudkan ketertiban dalam hidup bermasyarakat serta untk mengatur kehidupan antar manusia dalam berinteraksi dengan sesamaanya, sedangkan norma kesusilaan merupakan norma yang mengatur dan mengendalikan tutur tata, sikap dan perirlaku setiap maisng-masing indivudu melalui hati nurani pribadi yang bersangkutan. Artinya dalam memproduksi dan memberikan suatu tayang sebuah iklan produk, maka perlu kiranya untuk memperhatikan norma kesopanan dan norma kesusilaan karena iklan yang diproduksi tersebut kemudia akan ditayangkan dan ditonton oleh masyarakat.

Seorang konsumen juga mendapatkan Hak Konsumen yakni Hak atas kenyamanan, keamanan, dan keselamatan dalam mengkonsumsi barang dan/atau jasa (Pasal 4 huruf a UU No. 8 Tahun 1999 tentang Perlindungan Konsumen. Untuk menunjukan bahwa masyrakat merupakan konsumen yang mengkonsumsi siaran iklan yang diproduksi oleh perusahaan periklanan digunakan salah satu konstruksi hukum yakni argumentum per analogiam atau biasa disebut analogi. Analogi adalah metode konstruksi untuk mendapatkan dan menerapkan undang-undang pada peristiwanya hakim akan memperluasnya dengan tujuan untuk mengetahui peristiwa yang serupa sejenis atau mirip dengan yang diatur dalam undang-undang diperlukan sama. ${ }^{9}$ Analogi digunakan untuk menunjukkan bahwasannya masyarakat merupakan konsumen yang mengkonsumsi suatu tayangan iklan pada televisi berhak untuk memperoleh kenyaman, keamanan, dan keselamatan dalam menonton (mengkonsumsi) suatua tayangan iklan. Maka diperlakukan sebagai berikut, ketika suatu perusahaan periklanan melakukan produksi suatu iklan, maka hasil dari produksi tersebut berupa suatu produk barang (tayangan iklan), kemudian iklan tersebut ditayangkan di stasiun televisi dan iklan tersebut ditonton (mengkonsumsi) oleh masyarakat, terlebih juga anak-anak. Berdasarkan konstruksi hukum tersebut masyarakat selaku konsumen diperlakukan aturan yang sama pula untuk mendapatkan hak atas kenyamanan, keamanan, dan keselamatan dalam mengkonsumsi suatu barang dan/atau jasa sebagaimana dalam ketentuan Pasal 4 huruf a UU No. 8 Tahun 1999 tentang Perlindungan Konsumen.

\footnotetext{
${ }^{9}$ Sudikno Mertokusomo, Mengenal Hukum Suatu Pengantar, Yogyakarta: Liberty, 2008, hlm. 176.
} 
Dialogia luridica: Jurnal Hukum Bisnis dan Investasi

Vol. 11 (1): 062- 076

Pertanggungjawaban perdata (tanggung gugat) dalam ranah hukum perdata umumnya diwujudkan dalam bentuk kompensasi atau pemberian ganti kerugian. Pengertian kerugian secara luas dikemukakan oleh J.H. Nieuwenhuis adalah berkurangnya harta kekayaan salah satu pihak akibat pelanggaran norma oleh pihak lain (melakukan/membiarkan ${ }^{10}$ ), yang relatif bertumpu pada suatu perbandingan antara dua keadaan. Dengan demikian kerugian merupakan selisih yang merugikan antara keadaan yang diperoleh sebagai akibat pelanggaran norma, dan dengan keadaan yang seharusnya dan situasi yang seyogyanya akan diperoleh seandainya tidak terjadi pelanggaran norma tersebut ${ }^{11}$.

Prinsip tanggung gugat dalam siaran iklan menggunakan tanggung gugat berdasarkan unsur kesalahan (liability based on fault) adalah prinsip yang cukup lama berlaku dalam hukum perdata. Dalam KUHPerdata, khususnya Pasal 1365, 1366, dan 1367, prinsip ini dipegang secara teguh. Prinsip ini menyatakan, seseorang baru dapat diminta pertanggungjawabannya secara hukum jika ada unsur kesalahan yang dilakukan yang sebagaimana mengharuskan terpenuhinya lima unsur pokok yaitu.:

1. Adanya suatu perbuatan

2. Perbuatan tersebut melawan hukum

3. Adanya kesalahan dari pihak pelaku

4. Adanya kerugian bagi korban

5. Adanya hubungan klausal antara perbuatan dengan kerugian.

Berkaitan pertanggungjawaban atas iklan yang diproduksi dan disiarkan ada dua pasal terkait mengenai pertanggungjawaban

1. Pasal 20 Undang-Undang Nomor 8 Tahun 1999 Tentang Perlindungan Konsumen "pelaku usaha periklanan bertanggung jawab atas iklan yang diproduksi dan segala akibat yang ditimbulkan oleh iklan tersebut"

2. Pasal 46 ayat (5) Undang-Undang 32 Tahun 2002 Tentang Penyiaran "siaran iklan Niaga yang disiarkan menjadi tanggung jawab lembaga penyiaran"

\footnotetext{
${ }^{10}$ J.H Niuewenhuis, terjemahan Jasadin Saragih, Pokok-Pokok Hukum Perikatan, Surabaya: Airlangga University Press, 1985, hlm 54.

${ }^{11}$ Ibid, hlm 67.
} 
Dialogia luridica: Jurnal Hukum Bisnis dan Investasi

Vol. 11 (1): 062- 076

Pertanggungjawaban bagi pelaku usaha periklanan diatur dalam pasal $20 \mathrm{UU}$ Perlindungan Konsumen yang menyatakan "pelaku usaha periklanan bertanggung jawab atas iklan yang diproduksi dan segala akibat yang ditimbulkan oleh iklan tersebut". Pasal ini telah cukup jelas menyatakan keharusan mutlak pelaku usaha periklanan untuk bertanggung jawab atas iklan yang diproduksi. Secara sederhana dan lazim pelaku usaha periklanan disamakan dengan pelaku usaha biasa karena memiliki karakteristik yang sama yaitu sebagai produsen. Pelaku usaha biasa merupakan produsen produk sementara pelaku usaha periklanan merupakan produsen iklan.

Pada umumnya masyarakat tidak menyadari bahwa iklan juga merupakan produk. Mereka mengidentikan produk melalui sebagai barang yang tangible atau setidaknya jika produk tersebut berupa jasa maka adalah jasa yang bersifat personal, dalam arti tidak "dikonsumsi" secara massif, serta tidak memiliki efek "konsumsi" yang nyata dan langsung terasa, seperti potong rambut, penjahit pakaian. Padahal iklan sebagai susuatu yang bersifat abstrak (karena bermain diarena psikis) dan cenderung massif adalah juga sesuatu yang tidak ada jika tidak diproduksi oleh produsen.

Dari kesamaan karakteristik pelaku usaha biasa dengan usaha periklanan, serta kesamaan antara produk dengan produk berupa iklan, makal pasal 19 ayat (1) berlaku juga untuk pelaku usaha periklanan. Bias dianggap bahwa pasal 19 ayat (1) UU Perlindungan Konsumen merupakan ketentuan umum bagi pelaku usaha periklanan, sedangkan pasal 20 merupakan ketentuan khususnya.

\section{Upaya Hukum Yang Dapat Ditempuh Konsumen}

Dalam kasus iklan "SidoSusu" masyarakat selaku konsumen menurut kami setelah menonton iklan tersebut yang ditayangkan di televisi terdapat kerugian immaterial. Yang dimaksud kerugian immaterial, merupakan Kerugian Immaterial, immaterial menurut terminologi hukum diartikan "tidak bisa dibuktikan" sehingga kerugian immaterial merupakan kerugian yang diderita akibat perbuatan melawan hukum yang tidak dapat dibuktikan, dipulihkan kembali dan atau menyebabkan kesenangan hidup sementara, ketakutan, sakit, dan terkejut sehingga tidak dapat dihitung berdasarkan uang.

Adanya kerugian tersebut konsumen memiliki hak untuk memulihkan akibat kerugian yang dideritanya maka dengan ini konsumen memiliki legal standing untuk 
Dialogia luridica: Jurnal Hukum Bisnis dan Investasi

Vol. 11 (1): 062-076

melakukan penyelesaian sengketa dalam bidang konsumen tentu hal ini merujuk pada ketentuan pasal 45 ayat (1) UU Perlindungan Konsumen " setiap konsumen yang dirugikan dapat menggugat pelaku usahamelalui lembaga yang bertugas menyelesaikan sengketa antara konsumen dan pelaku usaha atau melalui peradilan yang berada di lingkungan peradilan umum".

Mengingat kerugian yang ditimbulkan dari siaran iklan berdampak massif dan dirasakan oleh banyak konsumen yang tentunya jumblahnya tidak sedikit, dan memiliki kepentingan yang sama akibat kerugian yang dialaminya maka konsumen lebih tepat untuk memulihkan haknya mengajukan gugatan perwakilan kelompok sebagaimana dalam sistem hukum Indonesia telah diadopsi dengan diundangkannya Perma Nomor 1 Tahun 2002 Tentang Acara Gugatan Perwakilan Kelompok.

Legal standing terhadap gugatan perwakilan kelompok yang diajukan oleh konsumen dengan kepetningan yang sama dapat ditemua pada pasal 46 ayat (1) yang berbunyi " gugatan atas pelanggaran pelaku usaha dapat dilakukan oleh:

a) Seorang konsumen yang dirugikan atau ahli waris yang bersangkutan

b) Sekelompok konsumen yang memeiliki kepentingan yang sama

c) Lembaga perlindungan konsumen swadaya masyarakat yang memenuhi syarat, yaitu berbentuk badan hukum atau yayasan yang dalam anggarannya menyebutkan dengan tegas bahwa tujuan didirikannya organisasi tersebut adalah untuk kepentingan perlindungan konsumen dan telah melaksanakan kegiatan sesuai anggaran dasarnya

d) Pemerintah dan atau instansi apabila barang dan/atau jasa yang dikonsumsi atau dimanfaatkan mengakibatkan kerugian materi yang besar dan/atau korban yang tidak sedikit.

Gugatan perwakilan sekelompok konsumen diajukan kepada peradilan umum sebagaimana gugatan tersebut merupakan gugatan perdata namun menggunakan prosedur dalam Perma Nomor 1 Tahun 2002 Tentang Acara Gugatan Perwakilan Kelompok.

Perwakilan kelompok atau class action secara umum class action merupakan sininim class suit/ representative action yang berarti: ${ }^{12}$

\footnotetext{
${ }^{12} \mathrm{M}$ Yahya Harahap, Hukum Acara Perdata Tentang Guagatan, Persidangan, Penyitaan, Pembuktian, Dan Putusan Pengadilan, Jakarta: Sinar Grafika, 2017, hlm 187.
} 
Dialogia luridica: Jurnal Hukum Bisnis dan Investasi

Vol. 11 (1): 062- 076

a) Gugatan yang berisi tuntutan melalui proses pengadilan yang diajukan oleh satu atau beberapa orang yang bertindak sebagai wakil kelompok (class representative);

b) Perwakilan kelompok itu bertindak mengajukan gugatan tidak hanya untuk dan atas nama mereka, tetapi sekaligus untuk dan atas nama kelompok yang mereka wakili, tanpa memerlukan surat kuasa dari anggota kelompok;

c) Dalam pengajuan gugatan tersebut, tidak perlu disebutkan secara individual satu persatu identitas anggota kelompok yang diwakili;

d) Yang penting, asal kelompok yang diwakili dapat didefinisikan identifikasi anggota kelompok secara spesifik;

e) Selain itu, antara seluruh anggota kelompok, dengan wakil kelompok dapat kesamaan fakta atau dasar hukum yang melahirkan:

1) Kesamaan kepentingan

2) Kesamaan penderitaan, dan

3) Apa yang dituntut untuk syarat kemanfaatan bagi seluruh anggota.

Sedangkan secara yuridis pengertian gugatan perwakilan kelompok melihat pada ketentuan pasal 1 huruf a Perma Nomor 1 Tahun 2002, gugatan perwakilan kelompok adalah suatu tata cara pengajuan gugatan dalam mana satu orang atau lebih mewakili kelompok mengajukan gugatan untuk diri atau ciri-ciri mereka sendiri dan sekaligus mewakili kelompok orang yang jumlahnya banyak, yang memeiliki kesamaan fakta atau dasar hukum antara wakil kelompok dan anggota kelompok dimaksud.

Adapun persyaratan formal surat gugatan perwakilan kelompok harus memenuhi sebagaimana diatur dalam hukum acara perdata yang berlaku persyaratan formal tersebut diatur dalam pasal 3 ayat (1) Perma Nomor 1 Tahun 2002 antara lain sebagai berikut:

a) Identitas lengkap dan jelas wakil kelompok;

b) Defisini kelompok secara rinci dan spesifik Walaupun tanpa menyebutkan nama anggota kelompok satu per satu;

c) Keterangan tentang anggota kelompok yang diperlukan dalam kaitan dengan kewajiban melakukan pemberitahuan; 
d) Posita seluruh kelompok baik wakil kelompok maupun anggota kelompok, yang ter identifikasi maupun tidak ter identifikasi yang dikemukakan secara jelas dan terinci;

e) Dalam suatu gugatan, dapat dikelompokan beberapa bagian kelompok atau subkelompok, jika tuntutan tidak sama karena sifat dan kerugiannya berbeda;

f) Tuntutan dan atau petitum gantirugi harus dikemukakan secara jelas dan rinci memuat usulan tentang mekanisme atau tata cara pendistribusian ganti kerugian kepada keseluruhan anggota kelompok termasuk ususlan tentang pembentukan tim atau panel yang membantu memperlancar pendistribusian ganti kerugian.

\section{PENUTUP}

Kriteria iklan yang mudah didapati mengandung unsur pornografi yakni iklan niaga atau iklan yang bersifat komersial. Hal tersebut dibuktikan dengan adanya surat teguran yang dikeluarkan oleh KPI, serta materi muatan pada iklan tersebut berisi terkait promosi barang (produk) disertai adegan yang tidak pantas diperagakan dalam suatu iklan. Artinya iklan tersebut juga harus mematuhi norma kesopanan dan norma kesusilaan disamping juga mentaati ketentuan peraturan perundang-undangan. Manakala pelaku usaha menayangkan materi muatan iklan yang tidak sesuai dengan peraturan perundangundangan maka akan menimbulkan akibat hukum berupa sebuah pertanggungjawaban akibat tayangan iklan tersebut.

Masyarakat tidak menyadari bahwa iklan juga merupakan produk. Mereka mengidentikan produk melalui sebagai barang yang tangible atau setidaknya jika produk tersebut berupa jasa maka adalah jasa yang bersifat personal, dalam arti tidak "dikonsumsi" secara massif, serta tidak memiliki efek "konsumsi" yang nyata dan langsung terasa, seperti potong rambut, penjahit pakaian. Padahal iklan sebagai susuatu yang bersifat abstrak (karena bermain diarena psikis) dan cenderung massif adalah juga sesuatu yang tidak ada jika tidak diproduksi oleh produsen.

Dari kesamaan karakteristik pelaku usaha biasa dengan usaha periklanan, serta kesamaan antara produk dengan produk berupa iklan, makal pasal 19 ayat (1) berlaku juga untuk pelaku usaha periklanan. Bias dianggap bahwa pasal 19 ayat (1) UU Perlindungan Konsumen merupakan ketentuan umum bagi pelaku usaha periklanan, sedangkan pasal 20 merupakan ketentuan khsusnya. 
Dialogia luridica: Jurnal Hukum Bisnis dan Investasi

Vol. 11 (1): 062- 076

Mengingat kerugian yang ditimbulkan dari siaran iklan berdampak massif dan dirasakan oleh banyak konsumen yang tentunya jumlahnya tidak sedikit, dan memiliki kepentingan yang sama akibat kerugian yang dialaminya maka konsumen lebih tepat untuk memulihkan haknya mengajukan gugatan perwakilan kelompok sebagaimana dalam sistem hukum Indonesia telah diadopsi dengan diundangkannya Peraturan Mahkamah Agung Nomor 1 Tahun 2002 Tentang Acara Gugatan Perwakilan Kelompok.

\section{DAFTAR PUSTAKA}

\section{Buku}

Ahmadi Miru dan Sutarman Yodo, Hukum Perlindungan Konsumen, Depok: Rajawali Pers, 2017.

Az. Nasution, Hukum Perlindungan Konsumen Suatu Pengantar, Jakarta: Diadit Media, 2014.

Janus Sidobalok, Hukum Perlindungan Konsumen Di Indonesia, Bandung: Citra Aditya, 2014.

J.H Nieuwenhuis, Pokok-Pokok Hukum Perikatan, Terjemahan Djasadin Saragih, Surabaya Universitas Arilangga Press, 1985.

Mardian Wibowo, Iklan Televisi dan Perlindungan Hukum Bagi Konsumen, Bandung: Mandar Maju, 2018.

Munir Fuadi, Perbuatan Melawan Hukum Pendekatan Kontemporer, Bandung: Citra Aditya Bakti, 2017.

M. Yahya Harahap, Hukum Acara Perdata Tentang Gugatan Persidangan, Penyitaan, Pembuktian, dan Putusan Pengadilan, Jakarta: Sinar Grafika, 2017.

\section{Peraturan Perundang-undangan}

HIR/RIB

Kitab Undang-Undang Hukum Perdata.

Undang-Undang Nomor 8 Tahun 1999 Tentang Perlindungan Kosumen.

Undang-Undang Nomor 32 Tahun 2002 Tentang Penyiaran.

Peraturan Mahkamah Agung RI Nomor 1 Tahun 2002 Tentang Gugatan Aacara Perwakilan Kelompok. 